\title{
A Study on Growth of Hotel Industry in Goa
}

\author{
S.V Sukthankar \\ Associate Professor of Commerce Government College, Khandola,Marcela Goa.
}

\begin{abstract}
The paper has made an attempt to explain what tourism is and tourism related (accommodation) hotel industry. The paper traces the origin and development of tourism and hotel industry in the state of Goa along with significance and evil effects. The article studies the growth of domestic and foreign tourist arrivals in Goa during the period 2000 to 2012. It is observed that the arrival of domestic tourist and foreign tourist in Goa is showing an increasing trend. Similarly the hotels, rooms and beds are also showing a healthy growth. The tourist arrivals in Goa show annual compound growth rate of 6.78\%, where as the hotels show a compound growth rate of $4.07 \%$.
\end{abstract}

Keywords: Accommodation, Domestic tourist, foreign tourist, Goa, Hotel Industry.

\section{Introduction}

Since the earliest times man has traveled in search of food, shelter and for satisfaction of his requirements. Travel has been a decisive factor in the economic, social, cultural, spiritual and artistic development of society. The first nomad who wondered with his movable dwellings in search of food and shelter from one place to another must have been stuck by variations in ecology. So there was gradual shift from unintended pleasure out of travel to traveling exclusively for pleasure.

Tourist is a population, which normally travels to predetermined destinations for whatever purpose, consumes tourism products while traveling and returns home after a short period

Tourism became a major industry, only after the world war-II. It is now recognized as an activity generating a number of social and economic benefits. It also creates employment opportunities. Besides promoting national and international understanding, it helps the international economy and raises the living standards of the people with comparatively less investment, unlike many other capital incentive industries. Tourism today represents around $6 \%$ of the global trade and almost $13 \%$ of the global consumer spending

\subsection{Tourism Related [ Accommodation] Hotel Industry}

The word 'Accommodation' has its origin in the Greek word Xenia; by which the, ancient Greek meant not only hospitality but also all forms of protection given to visiting strangers, philosophers, intellectuals, and researchers. The guests then were invited to stay in the dwellings of noble man. As traveling become more frequent accommodation for travelers came to be viewed in two different ways. The travelers who left their comfortable homes required equally comfortable accommodation during touring, 'inns' were introduced, where travelers were offered food and shelter with add on comforts. Payment for accommodation being used began to be charged from 15th century onwards. The institution of inns came to be developed in several countries in Europe particularly in England and France. The English House of Commons declared the inn to be a public house and proposed social responsibility on the innkeepers for the well being of the travelers. In the USA, Samuel Coles started another form of accommodation in 1934 called the tavern where people used to come for food, drinking and entertainment.

\subsection{Significance Of The Study}

The expansion of tourism will inherently bring about development of tourist accommodation facilities. In tourism, accommodation sector solely represents one of the fundamental pillars, the other being travel and amusement Today, a number of factors are coming into a proper focus and it is becoming increasingly evident that what once has been considered as a separate hotel industry is now an integral part of the larger tourism industry, because 'no hotels no tourism'. The hotel industry is so closely linked with the tourism industry that it is responsible for $50 \%$ of foreign exchange earnings. The tourism industry plays an important role in the development of a region. It becomes significant to study the growth of tourist arrivals in particular and hotels in general as they are required for effective tourism planning. By understanding the growth of tourist arrivals and hotels the government, entrepreneurs and investors can plan their activities more effetely. Keeping the growing importance of tourist arrivals and hotel industry for growth of tourism industry the following objectives are laid down. 


\subsection{Objectives}

1.3.1 To study the growth of tourist arrivals in Goa

1.3.2 To study the growth of hotels in Goa.

\subsection{Sources Of Data}

The study is based on the secondary data which is collected and compiled from various statistical Bulletins from Directorate of Tourism, Government of Goa.

\subsection{Period Of Study}

The period of study is from the year 2000 to 2012 .

\section{GOA}

India became Independent in the year 1947, but the tiny State of Goa joined the national mainstream only a decade and half later. Known as the seat of intellect and enterprise, Goa enjoys a unique combination of nature's endowments.

Goa, liberated along with Daman \& Diu from the Portuguese rule on December 19, 1961, became a full-fledged State on 30th May, 1987. The State of Goa has an area of 3,702 sq. kms, is divided for administrative purposes into two districts, North Goa and South Goa, with effect from 15th August 1987, with their Headquarters at Panaji and Margao, respectively. The State is bound on the North by Maharashtra, on the East and South by Karanataka and the West by the Arabian Sea. Goa has a population of 13.48 lakhs as per 2001 Census.

Goa receives rains from the South-West monsoons between the months of June and September. The average rainfall is $3200 \mathrm{~mm}$. temperate weather prevails during the rest of the year with little or no clear cut demarcation between what is generally termed as winter and summer. The range of temperature varies from $15.7^{\circ} \mathrm{C}$ to $35.6^{\circ} \mathrm{C}$.

The State is intersected by an extensive network of waterways. The most important rivers are Mandovi, Zuari, Tiracol, Chapora, Sal and Talpona. All these rivers have their origin in the Sahyadri ranges and flow westward into the Arabian Sea. They serve as inland waterways, being navigable in the lower and mostly tidal reaches. Lakes constitute a scenic feature of Goa. The most popular among them are Mayem Lake and Carambolim, the former being today a picturesque tourist resort.

Framed in legend as the land created by Lord Parashuram and, in history, as Golden Goa coveted by princes and potentates down the centuries since Vedic times, through successive rules of Rastrakutas, Silaharas, Chalukyas, the Bahamani Muslim Kings and 451 years long Portuguese domination, Goa is today known nationally and internationally as a most preferred tourist destination.

Goa, apart from its historicity, is also renowned for its scenic beauty. Indeed, it is a tiny paradise with some of the loveliest beaches of the world girdling its $105 \mathrm{kms}$, long palmfringed coast, interspersed with enchanting coves and estuaries against a backdrop of green hills covered with lovely woods, rolling down to emerald paddy fields, cool and shady coconut palms, cashew and mango groves dotted with tiny picturesque villages, towns, temples, churches, mosques, forts and monuments which offer a fantastic panoramic kaleidoscope of unrivaled beauty.

Lavishly gifted by nature, Goa can also boast of unique and distinctive creations of human imagination and talent - from dainty handicrafts to majestic cathedrals, charming baroque villas, nestling amidst gardens to grim forts, the silent eloquent witnesses of an embattled past.

The rich heritage of Goa is expressed in the traditional folk music, dance, drama and literature, colorful festivals, pageants and feasts besides the superb specimen of temple architecture like Mangeshi, Shantadurga, Tambdi Surla, Basilica of Bom Jesus and Se Cathedral, otherwise no less renowned as centers of worship and pilgrimage for devotees flocking there round the year.

\subsection{Tourism In Goa}

Although Goa joined the national mainstream only after 14 years of the country's Independence, it started attracting tourists straightway. With the creation of basic infrastructural facilities like roads, electricity, water supply, accommodation facilities, etc., after 
its liberation from the Portuguese Rule, low and middle income group tourists who constitute the bulk of domestic tourist traffic, started descending onto Goa in organized groups.

The harmonious blend of east and west attracts both the Indian and foreign travelers into Goa. Today it is one of the few tourist attractions where even middle and lower middle class people can enjoy a comfortable vacation. ${ }^{1}$

The Portuguese legacy of an annual carnival, along with different dress codes for women, for instance, were viewed by non-Goan Indians as a mark of westernization. The presence of a significant number of Western Hippies in the State from the mid-1960's onwards further enhanced this image of Goa as being different from the rest of India, especially since the behavior and life-styles of the hippies were so widely at odds with the values and mores of the indigenous society.

The growing number of western women tourist sunbathing topless and forming casual sexual relationship with local men further sexualized Goa, reinforcing the general stereotype image the non-Goan Indians held of Goa as a Westernized and liberal State. ${ }^{2}$

\subsection{Evil Effects Of Tourism In Goa}

Tourism is not an unmixed blessing. If we turn the coin, the ill consequences of tourism on the society are brought to light like ecological and environmental degradation, commercialization of culture, over-exploitation of community resources, and destruction of livelihood of the local populace. Social tensions mount from unplanned tourism growth. Flora and fauna may suffer degradation if overexposed by tourist population. Nudism, drug abuse, flesh trade, etc., are some other maladies that tourism industry imports into the host community. Goa is an example. This affects the local culture. Local traditions and festivals are increasingly projected to the 5-Star customers. In the process, the traditional forms of art, music, dance and festivals are slowly and surely giving away to twist the taste and tune of 5 Star customers ${ }^{3}$

\subsection{Future Of Tourism In Goa}

Nature has been generous to Goa by giving it a tourist infrastructure which should be the envy of many regions and with the experience of the last few decade, it should be possible for the Government to plan this sector, consciously, methodically and carefully by ensuring that its tourism policy harmonizes with its industrial policy and that the social costs of developing this sector does not outweigh its benefits and that its contribution to the State's domestic product improves impressively over years. Experts have opined that high-volume, high density mass tourism is not advisable for Goa, as this would accentuate the negative features of tourism and will result in gross mismatch between economic benefits and social costs. What Goa needs is a planned, controlled and well co-ordinated tourism policy. ${ }^{4}$

\subsection{Role Of Hotels For Tourism Promotion In Goa}

By far, Goa is the most successful example of Indian planning in beach tourism, though the Government's role in tourism development in Goa in the early 1960 s was minimal. The Taj Group of Hotels took the initiative in building Fort Aguada Beach Resort in Goa, a single complex of three hotels. Although Goa was known for its fantastic beaches and unique Portuguese cultural ambience in the East, there were no good hotels on the beaches. The Taj Resort was so good and beautiful that the late Prime Minister Mrs. Indira Gandhi invited the Heads of Commonwealth States for a brief holiday in Goa in 1983. The photographs of Prime Ministers and Presidents of several Commonwealth States enjoying a beach holiday in Goa appeared all over the world, making Goa a popular destination for foreign visitors. At first, there were no direct charter flights to Goa. Once the charter flights were allowed, there was no stopping the development of other hotel chains like Welcome Group, Oberoi, and Ramada Inn. ${ }^{5}$

\section{1trend In Domestic Tourist Arrivals}

\section{Growth Of Tourist Arrivals In Goa}

The arrivals of domestic as well as foreign tourists are showing an increasing trend over the years as shown in the following Table 1.1. The total numbers of domestic tourist arrivals were $9,76,804$ in the year 2000 , the figure of domestic tourists increased to $19,65,343$ in the year 2005. By the end of 2010, the domestic tourist arrivals in Goa touched 22,01,752. 
By the end of 2012 Goa received a total of 23,37,499 domestic tourist. The domestic tourist arrivals have shown an increase over the years, except in the year 2005and 2008. The highest percentage increase as compared to the previous year is observed in the year 2003 with $30.17 \%$. From the year 2000 onwards, the arrivals of domestic tourist are showing an increasing trend.

\section{2trend In Foreign Tourist Arrivals}

The numbers of foreign tourist arrivals to Goa were 2,91,709 in the year 2000, which increased to 3,36,803 in the year 2005. By the end of 2010, Goa received 4,41,053 foreign tourists which subsequently increased to 4,50,530 at the end of 2012. The decline in foreign tourist arrivals is seen in the year 2001, 2005 and 2008. The highest percentage arrivals as compared to previous year is observed in the year 2010 with $17.10 \%$ and followed by the year 2003 with $15.72 \%$.

\subsection{1trend In Total Tourist Arrivals}

Similarly, the total tourist arrivals have also shown a more or less similar trend over the period. The total tourist arrivals were $12,68,513$ in the year 2000 , which increased to $23,02,146$ in the year 2005. By the end of 2010, the total tourist arrivals in Goa were $26,42,805$, which further increased to $27,88,029$ by the end of 2012 .

Table 1.1

Domestic and Foreign Tourist Arrivals in Goa : 2000 to 2012

\begin{tabular}{lcccccc} 
Year & Domestic & \% Change & Foreign & \% Change & Total & \% Change \\
& & & & & & \\
2000 & $9,76,804$ & 1.74 & $2,91,709$ & 2.61 & $12,68,513$ & 1.9 \\
2001 & $11,20,242$ & 14.68 & $2,60,071$ & -10.85 & $13,80,313$ & 8.8 \\
2002 & $13,25,296$ & 18.30 & $2,71,645$ & 4.45 & $15,96,941$ & 15.7 \\
2003 & $17,25,140$ & 30.17 & $3,14,357$ & 15.72 & $20,39,497$ & 27.7 \\
2004 & $20,85,429$ & 20.90 & $3,63,230$ & 15.55 & $24,48,959$ & 20.1 \\
2005 & $19,65,343$ & -5.77 & $3,36,803$ & -7.28 & $23,02,146$ & -6.0 \\
2006 & $20,98,654$ & 6.78 & $3,80,414$ & 12.95 & $24,79,068$ & 7.7 \\
2007 & $22,08,986$ & 5.25 & $3,88,457$ & 2.11 & $25,97,443$ & 4.8 \\
2008 & $20,20,416$ & -8.53 & $3,51,123$ & -9.61 & $23,71,539$ & -8.7 \\
2009 & $21,27,063$ & 5.27 & $3,76,640$ & 7.26 & $25,03,703$ & 5.6 \\
2010 & $22,01,752$ & 3.51 & $4,41,053$ & 17.10 & $26,42,805$ & 5.5 \\
2011 & $22,25,002$ & 1.05 & $4,45,935$ & 1.10 & $26,70,937$ & 1.1 \\
2012 & $23,37,499$ & 5.05 & $4,50,530$ & 1.03 & $27,88,029$ & 4.38 \\
2013 & $3,66,033(\mathbf{P})$ & & $1,31,450(\mathbf{P})$ & & $4,97,483(\mathbf{P})$ & \\
\hline
\end{tabular}

Upto Feb,13 provisional

Source: Department of Tourism, Government of Goa

\section{Hotel Industry In Goa}

The origin of hotels in Goa goes back to a few hundred years when 'Brahmanis' were started near the famous temples of Mhalsa near Mardol, Shree Shantadurga in Kavale and some other places like Margaon, Sanquelim and Pernem. The facilities at Brahmanis were confined to the use only by a few people who probably came there for religious purposes. During mid-18th century, the European concept of 'Carnival' was introduced in Goa and was soon indigenized, attracting more and more people to the Carnival sites. This temporary movement of people, although not 'tourism' in the strictest sense, of course, gave rise to an 'accommodation problem', especially during the peak November-February season, forcing many to sleep in the open after knocking on the doors of every hotel and lodging houses, and others to go back home on the very day of their arrival.

In the year 1918 the first hotel was established at Vasco-da-gama by Britishers called as Palace Hotel to meet the growing requirement of sailors. This hotel was called as Hotel Palacio by the Portuguese. During the world war II there were only three Hotel Aliados in Goa one each at Panjim, Mapusa and Margao. ${ }^{6}$ 
Gradually, becoming conscious of the tourism potential of Goa, the establishing of hotels, motels and restaurants became a profound economic activity in the region, bringing in additional revenue for the government, increased incomes for the entrepreneurs, opening new avenues of employment for highly skilled to unskilled workforce in the hotel industry itself and also for those engaged in several tourism-related peripheral activities. In the capital city of Panjim itself and the nearby areas like Dona Paula, San Pedro, Ribandar and Betim, new hotels of all categories emerged.

The Hotel Mandovi in Panjim is a land mark and during Portuguese regime the only establishment of a standard in the whole of Goa. Facing river Mandovi it was built in 1952 and opened its doors to the public in December of that year on the occasion of the exposition of the relics of St Francis Xavier. High church dignitaries, members of royal families, ambassadors and statesman from many lands were its first guests. ${ }^{7}$

There has been an increase in the hotel and other type of accommodation in Goa. Today, Goa offers not only luxury Star hotels, but also inexpensive budget hotels, dormitories and paying guest accommodations. ${ }^{8}$

\subsection{GROWTH OF HOTEL INDUSTRY IN GOA}

Growth is the major objectives of any business undertaking, particularly firms belonging to private sector. Every hoteliering firm in the industry, irrespective of its size, location, and ownership, aspires to grow and expand. Hotel industry is not passive in nature to be satisfied and feel happy about its present status, occupancy rates, profitability, but it is dynamic in nature and aspires to have better growth rates. The hotels always plan to grow and expand their business in terms of increase in profitability, increase in occupancy rates, increase in market share, etc.

Accommodation facilities are the essential components of tourism products. Though these are attractions in themselves, their deficiency can deprive the tourist of a visit to a particular tourist destination. Hence, there is a need for sufficient number of hotels.

In a random survey of tourists, it was observed that among the foreign tourists, only a handful preferred to stay exclusively in 5-Star hotels, the remaining were not choosey about the hotel's Star rating but looked for good and comfortable accommodation at a reasonable price. Among the domestic tourists, the preference of the majority was for good accommodation with affordable price rather than luxury. ${ }^{9}$

The growth of hotel industry can be quantified by taking different variables like volume of investment, volume of production, occupancy rates, sales, employment, both direct and indirect, etc. However, the growth pattern of hotel industry in Goa is analyzed in terms of its capacity generation, which is represented by three different variables, namely, number of hotels established, number of let table rooms, and number of beds available. The data of these three variables are collected and compiled from the tourist statistics available with the Department of Tourism, Government of Goa. The data is analyzed for the period from 1-42000 to 31-3-2012 to discern a general trend for a longer duration.

Table 1.2

Total Number of Hotels in Goa : 31.3.2000 to 31.3.2012

$\begin{array}{cccccc}\begin{array}{c}\text { No.of } \\ \text { Hotels }\end{array} & \begin{array}{c}\text { Net } \\ \text { Increase }\end{array} & \begin{array}{c}\text { No.of } \\ \text { Rooms }\end{array} & \begin{array}{c}\text { Net } \\ \text { Increase }\end{array} & \begin{array}{c}\text { No.of } \\ \text { Beds }\end{array} & \begin{array}{c}\text { Net } \\ \text { Increase }\end{array} \\ 1,720 & -- & 14,922 & -- & 28,406 & -- \\ 1,833 & 113 & 16,084 & 1,162 & 30,617 & 2,211 \\ 1,893 & 60 & 16,585 & 501 & 31,649 & 1,032 \\ 1,933 & 40 & 17,342 & 757 & 33,139 & 1,490 \\ 2,027 & 94 & 18,346 & 1,004 & 34,914 & 1,775 \\ 2,156 & 129 & 19,130 & 784 & 36,378 & 1,464 \\ 2,233 & 77 & 20,085 & 955 & 37,999 & 1,621 \\ 2,322 & 89 & 20,844 & 759 & 39,335 & 1,336 \\ 2446 & 124 & 21,869 & 1,025 & 41,031 & 1,696 \\ 2,531 & 85 & 22,727 & 858 & 42,567 & 1,536 \\ 2,601 & 70 & 24,162 & 2,135 & 44,130 & 1,563 \\ 2,651 & 50 & 25,163 & 1,001 & 46,588 & 2,458 \\ 2,777 & 126 & 26,859 & 1,696 & 49,167 & 2,567\end{array}$

Note: Net increase indicates the rate of change over the previous year. 


\section{Source: Compiled from the Statistical bulletin, Department of Tourism, Government of Goa}

\subsubsection{Growth In Total Number Of Hotel, Rooms And Beds}

It is observed from Table 1.2 that the total number of hotels operating has shown a consistent increase from 1-4-00 to 31-3-12. The same trend is also observed in total number of lettable rooms and beds available. In the year 2000, the total numbers of hotels were 1,720, the total numbers of rooms were 14,922 and beds were 28,406 . These after a decade increased to 2,777 hotels, 26,859 rooms and 49,167 beds by the end of 31-3-12. There is a continuous and steady growth of all the three variables

The rate of change in the number of hotels during the period varied from lowest of 40 hotels in the year 31-3-03 and the highest in the year 31-3-05 with 129 new hotels. The corresponding increase in the number of rooms was lowest in the year 31-3-02 with 501 rooms and highest in the year 31-3-10 with 2,135 rooms. The increase in number of beds was lowest in the year 2002 with 1,032 beds, while the highest increase is observed in the year 31-3-2012 with 2,567 beds.

Table 1.3

\begin{tabular}{|c|c|c|c|c|c|c|}
\hline \multirow[b]{2}{*}{ Year } & \\
\hline & $\begin{array}{c}\text { Index of } \\
\text { hotels }\end{array}$ & $\begin{array}{c}\% \\
\text { Increase }\end{array}$ & $\begin{array}{l}\text { Index of } \\
\text { Rooms }\end{array}$ & $\begin{array}{c}\% \\
\text { Increase }\end{array}$ & $\begin{array}{c}\text { Index of } \\
\text { Beds }\end{array}$ & $\begin{array}{c}\% \\
\text { Increase }\end{array}$ \\
\hline 2001 & 106.56 & 6.56 & 107.78 & 7.78 & 107.78 & 7.78 \\
\hline 2002 & 110.05 & 3.27 & 111.14 & 3.11 & 111.41 & 3.37 \\
\hline 2003 & 112.38 & 2.11 & 116.21 & 4.56 & 116.66 & 4.71 \\
\hline 2004 & 117.84 & 4.86 & 122.94 & 5.79 & 122.91 & 5.35 \\
\hline 2005 & 125.35 & 6.37 & 128.19 & 4.27 & 128.06 & 4.19 \\
\hline 2006 & 129.82 & 3.57 & 134.59 & 4.99 & 133.77 & 4.45 \\
\hline 2007 & 135.00 & 3.99 & 139.68 & 3.78 & 138.47 & 3.51 \\
\hline 2008 & 142.20 & 5.33 & 146.55 & 4.91 & 144.44 & 4.31 \\
\hline 2009 & 147.15 & 3.48 & 152.30 & 3.92 & 149.89 & 3.77 \\
\hline 2010 & 151.22 & 2.76 & 161.92 & 6.31 & 155.35 & 3.64 \\
\hline 2011 & 154.12 & 1.91 & 168.63 & 4.14 & 164.00 & 5.56 \\
\hline 2011 & 161.45 & 4.75 & 180.06 & 6.74 & 173.08 & 5.53 \\
\hline
\end{tabular}

Note: \% increase indicates the percentage increase over the previous year.

Source: Compiled from the Statistical Bulletin, Department of Tourism, Government of Goa.

By measuring the indices of all the three variables, it is observed that these three variables have registered a steady and continuous increase (Table 1.3). The index of hotel has consistently increased to 161.45 , the index of room has increased to 180.06 and the index of bed has increased to 173.08 over the study period. Proportionately, the rate of increase in room capacity is more than in bed and hotels. The annual percentage increase regarding hotels, rooms and beds were found to be positive. The highest annual percentage change is found in the year 2001 in case of hotels, rooms and the beds as well. This change in years is due to the conversion of larger rooms into smaller rooms, and adding of beds in the existing rooms. This trend highlights the fact that a hotel may either be started with few rooms and beds or with large number of rooms and beds.

Table 1.4

Bed to Room Ratio, Mean Firm Size of Hotel

$\begin{array}{lcccccc}\text { Year } & \text { No.of } & \text { No.of } & \text { No.of } & \text { B/R } & & \\ 2000 & \text { Hotels } & \text { Rooms } & \text { Beds } & \mathrm{a}^{1} & \mathrm{X}^{1} & \mathrm{X}^{2} \\ 2001 & 1,720 & 14,922 & 28,406 & 1.90 & 8.68 & 16.52 \\ 2002 & 1,833 & 16,084 & 30,617 & 1.90 & 8.77 & 16.70 \\ 2003 & 1,893 & 16,585 & 31,649 & 1.91 & 8.76 & 16.72 \\ 2004 & 1,933 & 17,342 & 33,139 & 1.91 & 8.97 & 17.14 \\ 2005 & 2,027 & 18,346 & 34,914 & 1.90 & 9.05 & 17.22 \\ 2006 & 2,156 & 19,130 & 36,378 & 1.90 & 8.87 & 16.87 \\ 2007 & 2,233 & 20,085 & 37,999 & 1.89 & 8.99 & 17.02 \\ 2008 & 2,322 & 20,844 & 39,335 & 1.89 & 8.98 & 16.94 \\ 2009 & 2,446 & 21,869 & 41,031 & 1.88 & 8.94 & 16.77 \\ & 2,531 & 22,727 & 42,567 & 1.87 & 8.97 & 16.81\end{array}$




$\begin{array}{lllllll}2010 & 2,601 & 24,162 & 44,130 & 1.83 & 9.28 & 16.96 \\ 2011 & 2,651 & 25,163 & 46,588 & 1.85 & 9.49 & 17.57 \\ 2012 & 2,777 & 26,859 & 49,167 & 1.83 & 9.67 & 17.70\end{array}$

$\mathrm{a}^{1}=\mathrm{B} \backslash \mathrm{R}$ represents Bed-Room Ratio

$\mathrm{X}^{1}=$ Mean firm size according to number of rooms

$\mathrm{X}^{2}=$ Mean firm size according to number of beds.

From Table 1.4 , the $\mathrm{B} / \mathrm{R}$ ratio was found to vary between 1.83 to 1.91 . It is not a perceptible trend. This trend reveals that the industry is not multi bedded nor it is single bedded in character over the period. The bed per room ratio, more or less, remained around 1.85 , i.e. less than 2 . The mean size of the hotel as per room varied between 8.68 to 9.67 per hotel, while mean bed size per hotel varied between 16.52 to 17.70 .

\section{Summary and Conclusion}

The domestic tourist arrivals in Goa are increasing from the year 2000 onwards at the annual compound growth rate of 7.54 (Table 1.1). Similarly, the foreign tourist arrivals also show an annual compound growth rate of $3.69 \%$. It is also observed that the total tourist arrivals also show an increase at an annual compound growth rate of $6.78 \%$.

The Tourism Master Plan-2011 of the Government of Goa has forecast the domestic tourist arrivals at 19, 00,000 and foreign tourist arrivals at $11,30,000$ by the year 2021 . However, the domestic tourist arrivals have already reached 23, 37,499 by the year 2012 itself whereas the foreign tourist arrivals are lagging behind. So, we can say that the tourist arrivals are going to increase in Goa during the coming years.

The total hotels have showed an annual compound growth rate of $4.07 \%$ from the year 2000 to 2012 (Table 1.2). Hotel rooms are increasing at an annual compound growth rate of $5.02 \%$. Similarly, hotels beds have shown an annual compound growth rate of $4.68 \%$.

The Tourism Master Plan-2011 has estimated an additional bed requirement of 2,914 in Star category and 4,186 beds in non-Star categories of hotels by the end of 2021 .

We have observed that the hotel industry is progressing at a steady rate. This suggests that in future also, the hotel industry is going to grow with increases in both domestic and foreign tourist arrivals in Goa during the coming years.

The study is limited to the hotels which are registered under the Goa Tourism Trade Act, 1981, are taken up for study while Dharmsalas, youth hostels, company accommodations which offer multiple bed facilities are excluded for the period 2000 to 2012.

\section{Refference.}

[1]. Chattapadhyay, Kunal, Economic Impact of Tourism Development: An Indian Experience( Kanishka Publishers \& Distributors, 1995) p.55.

[2]. Chawla,Romila, SexTourism and Development (Sonali Publications, 2004) p.57

[3]. Angle, Prabhakar S, Goa :An Economic Update( Goa Hindu Association Kala Vibhag,2001) p.120-121.

[4]. Ibid., p.123.

[5]. Seth,Pran Nath,Successful Tourism ManagementVol.I: Fundamentals of Tourism( Sterling Publishers,1999) p. 145 .

[6]. Cabral e Sa, Mario,Goa Today March, p 17-18.

[7]. (1979): Goa Today December, p19-21.

[8]. Kumar, Ravi Bhushan,Costal Tourism and Environment(APH Publishing Corporation, 1995) p.154

[9]. Patil, P.B.,Tourism Development : Problems and Prospectus(Concept Publications,2006) p.56.

[10]. Mohanty, Pragati,Hotel Industry and Tourism in India ( Ashish Publishing House,1992)

[11]. Goa Tourism Trade Act, 1981.

[12]. Tourism Master Plan-, Government of Goa,2011.

[13]. National Council of Applied Economic Research,Techno-economic Survey of Goa, Daman and Diu 1964. 